\title{
MADU LEBAH KELULUT (Trigona Spp.) DALAM AKTIFITAS TERHADAP BAKTERI Staphylococcus aureus RESISTEN
}

\author{
M. Ma'ruf, Gina Alia Mawaddah, Nisa Nur Agistni Eriana, Farah Indah Swari, \\ Syaidatul Aslamiah, Leka Lutpiatina
}

Jurusan Analis Kesehatan Poltekkes Kemenkes Banjarmasin JI Mistar Cokrokusumo 4a Banjarbaru e-mail: zainalabidin@gmail.com

Abstract: Infection caused by Staphylococcus aureus bacteria becomes a very serious problem because of the increased resistance of these bacteria to various types of antibiotics. Honey has antibacterial activity because it contains water, acidity and inhibitor compounds namely flavonoids. Honey can be produced Trigona spp. This study aims to Minimum Inhibitory Concentration (MIC) and Minimum Bactericidal Concentration (MBC) and effectiveness of honey bee kelulut (Trigona spp.) Against Staphylococcus aureus resistant cephalosporin bacteria in vitro. This research is true experiment with postest only control group design. The results of the study were measured by MIC showed no clarity at concentrations of $60 \mathrm{mg} / \mathrm{ml}, 70 \mathrm{mg} / \mathrm{ml}, 80 \mathrm{mg} /$ $\mathrm{ml}, 90 \mathrm{mg} / \mathrm{ml}$ and and clarity at concentrations of $100 \mathrm{mg} / \mathrm{ml}$, and $M B C$ at concentrations of $60 \mathrm{mg} / \mathrm{ml}$ of 151 colonies, $70 \mathrm{mg} / \mathrm{ml}$ of 105 colonies, $80 \mathrm{mg} / \mathrm{ml}$ of 55 colonies, $90 \mathrm{mg} / \mathrm{ml}$ of 16 colonies and $100 \mathrm{mg} / \mathrm{ml}$ of 0 colonies. The effective concentration in killing Staphylococcus aureus resistant cephalosporin is $100 \mathrm{mg} / \mathrm{ml}$. Keyword : Trigona spp., Staphylococcus aureus resistent

Abstrak: Infeksi yang disebabkan oleh bakteri Staphylococcus aureus menjadi masalah yang sangat serius karena peningkatan resistensi bakteri ini terhadap berbagai jenis antibiotik. Madu memiliki aktivitas antibakteri karena mengandung air, keasaman dan senyawa inhibitor yaitu flavonoid. Madu dapat dihasilkan lebah Trigona spp. Penelitian ini bertujuan untuk mengetahui daya hambat minimal dan daya bunuh minimal serta efektivitas madu lebah kelulut (Trigona spp.) terhadap bakteri Staphylococcus aureus resisten sefalosporin secara in vitro. Penelitian ini bersifat true eksperiment dengan rancangan postest only control group design. Hasil penelitian diukur dengan Konsentrasi Hambat Minimal (KHM) menunjukkan tidak adanya kejernihan pada konsentrasi $60 \mathrm{mg} / \mathrm{ml}, 70 \mathrm{mg} / \mathrm{ml}, 80 \mathrm{mg} / \mathrm{ml}, 90 \mathrm{mg} / \mathrm{ml}$ dan dan adanya kejernihan pada konsentrasi $100 \mathrm{mg} / \mathrm{ml}$, serta Konsentrasi Bunuh Minimal (KBM) pada konsentrasi 60 $\mathrm{mg} / \mathrm{ml}$ sebanyak $151 \mathrm{koloni}, 70 \mathrm{mg} / \mathrm{ml}$ sebanyak $105 \mathrm{koloni}, 80 \mathrm{mg} / \mathrm{ml}$ sebanyak 55 koloni, $90 \mathrm{mg} / \mathrm{ml}$ sebanyak 16 koloni dan $100 \mathrm{mg} / \mathrm{ml}$ sebanyak 0 koloni. Konsentrasi yang efektif dalam membunuh bakteri Staphylococcus aureus resisten sefalosporin adalah $100 \mathrm{mg} / \mathrm{ml}$. Disarankan penelitian lebih lanjut mengenai efektifitas madu lebah kelulut (Trigona spp.) terhadap Staphylococcus aureus resisten antibiotik lain.

Kata Kunci: Madu Lebah Kelulut (Trigona spp.); Staphylococcus aureus resisten 


\section{PENDAHULUAN}

Staphylocccus aureus merupakan bakteri patogen penyebab infeksi nosokomial dan keracunan makanan. Penyebaran bakteri ini diudara dapat mengkontaminasi pangan, seperti halnya pada saos yang tercemar Staphylococcus aureus (1). Penelitian di rumah sakit terhadap 27 sampel swab hidung perawat menunjukkan adanya Staphylococcus aureus sebanyak $52 \%$ (2). Bakteri ini mempunyai daya tahan tinggi terhadap lingkungan dan bertahan hidup pada media dengan $\mathrm{NaCl} 10 \%$ (3).

Infeksi nosokomial adalah infeksi yang berasal dari rumah sakit. Rumah sakit dapat menjadi sumber penularan berbagai bakteri seperti Staphylococcus aureus maupun bakteri Gram negatif yang lain yaitu Pseudomonas sp dan Klebsiella sp. Sebuah penelitian menunjukkan adanya Pseudomonas dan Klebsiella pada kultur darah pasien bakteremia di Rumah sakit (4).Infeksi yang disebabkan oleh bakteri Staphylococcus aureus menjadi masalah yang sangat serius karena peningkatan resistensi bakteri ini terhadap berbagai jenis antibiotik (Multi Drug Resistance). Banyaknya penggunaan antibiotik yang tidak rasional merupakan salah satu faktor utama terjadinya resistensi antibiotik (5).

Berdasarkan survei yang dilakukan oleh Centers for Disease Control and Prevention (CDC) pada tahun 2013 di Amerika Serikat, setiap tahun setidaknya 2 juta manusia terkena infeksi bakteri yang resisten terhadap satu atau beberapa jenis antibiotik. Berdasarkan data World Health Organization (WHO) tahun 2009, Indonesia menduduki peringkat ke-8 dari 27 negara dengan beban tinggi resistensi antibiotik terhadap bakteri Multi Drug Resistance (MDR) di dunia.

Pengobatan penyakit infeksi yang disebabkan bakteri yang resisten terhadap antibiotik memerlukan obat dari bahan alam (obat tradisional) secara umum dinilai lebih aman dari pada penggunaan obat modern. Salah satu bahan alam yang diyakini secara empiris mempunyai banyak khasiat dan relatif aman adalah madu. Berbagai spesies lebah menghasilkan madu. Madu dipercaya memiliki aktivitas antibakteri. Madu dapat dihasilkan salah satunya dari lebah Trigona spp., lebah yang dikenal dengan nama kelulut di Kalimantan ini mudah ditemukan di lingkungan sekitar (6).

Daya hambat terhadap pertumbuhan enam spesies bakteri termasuk terhadap Staphylococcus aureus telah terbukti pada madu lebah Trigona spp asal Australia ${ }^{\text {. }}$ Daya hambat dan daya bunuh madu lebah Trigona spp asal Kalimantan terhadap Staphylococcus aureus resisten sefalosporin belum diketahui. Tujuan penelitian ini untuk mengkaji efektivitas madu lebah kelulut (Trigona spp.) terhadap bakteri Staphylococcus aureus resisten sefalosporin secara in vitro.

\section{BAHAN DAN METODE}

Jenis penelitian yang digunakan dalam penelitian ini adalah metode eksperimen. Rancangan penelitian yang digunakan dalam penelitian ini adalah Postest Only Control Group Design, yaitu dengan melakukan pemeriksaan konsentrasi hambat minimal (KHM) dan konsentrasi bunuh minimal (KBM) pada konsentrasi $60 \mathrm{mg} / \mathrm{ml}, 70 \mathrm{mg} / \mathrm{ml}, 80$ $\mathrm{mg} / \mathrm{ml}, 90 \mathrm{mg} / \mathrm{ml}$ dan $100 \mathrm{mg} / \mathrm{ml}$ kemudian dibandingkan dengan kelompok kontrol negatif, kontrol positif dan kontrol madu dengan jumlah pengulangan sebanyak 3 kali.

Madu lebah kelulut diambil dari beberapa sarang lebah kelulut (Trigona spp.) yang ada di Pelaihari Kalimantan Selatan. Lebah kelulut (Trigona spp.) dikenali dari ukurannya yang kecil, tidak bersengat, dangat lincah bergerak dan hidup berkelompok yang 
membuat sarang di celah-celah batu, lubang pohon dan bangunan manusia. Bahan lain yang digunakan adalah antibiotik kloramfenikol, media Trypticase Soy Broth (TSB) steril, media Coklat Agar steril, media Mannitol Salt Agar (MSA) steril, media Mueller Hinton Agar steril, media Nutrient Agar steril, media gula-gula steril (glukosa, laktosa, manitol, maltosa, sakarosa), pewarnaan gram metode Stain (larutan Gentian violet 1\%, larutan Lugol, alkohol 96\% dan larutan Safranin), plasma darah (sitrat), standar Mac Farland 0,5 , alkohol $70 \%$, propilen glikol, larutan $\mathrm{NaCl} 0,9 \%$ steril, aquades. Variabel bebas adalah konsentrasi madu lebah kelulut (Trigona spp.).Variabel terikat adalah Staphylococcus aureus resisten sefalosporin.

Prosedur Konsentrasi Hambat Minimal (KHM) yaitu dengan membuat pengenceran konsentrasi ditambahkan ibakteri dengan volume yang sama. Homogenkan dan diinkubasi selama 20 jam dengan suhu $37^{\circ} \mathrm{C}$ di dalam inkubator. Dilihat kekeruhan yang terjadi. Prosedur Konsentrasi Bunuh Minimal $(\mathrm{KBH})$ dilakukan dengan 0,5 $\mu$ larutan dari tabung yang menunjukkan kejernihan pada KHM disebar pada nutrient agar (NA), kemudian dilihat konsentrasi yang sama sekali tidak menunjukan pertumbuhan koloni (7).

Data yang diperoleh secara kuantitatif dari hasil penentuan konsentrasi hambat minimum dan konsentrasi bunuh minimum terhadap bakteri Staphylococcus aureus resisten sefalosporin ditabulasikan dalam bentuk tabel. Analisis data dilakukan secara statistik menggunakan one way Anova dan uji post hoc LSD pada software komputer dengan syarat data bertipe kuantitatif/numerik, baik interval/rasio, berdistrubusi normal, homogen dengan $a=0,05$ pada taraf kepercayaan $95 \%$.

\section{HASIL DAN PEMBAHASAN}

Pengujian antimikroba madu lebah kelulut (Trigona spp.) terhadap Bakteri Staphylococcus aureus memperlihatkan adanya tingkat kejernihan pada penentuan Konsentrasi Hambat Minimal (KHM) yang dapat dilihat pada tabel 1 sebagai berikut.

Tabel 1 Hasil Konsentrasi Hambat Minimal (KHM)

\begin{tabular}{lllll}
\hline Konsentrasi & \multicolumn{3}{c}{ Tingkat kejernihan } & \multirow{2}{*}{ Kesimpulan } \\
\cline { 2 - 4 } & I & II & III & \\
\hline $60 \mathrm{mg} / \mathrm{ml}$ & Keruh & Keruh & Keruh & Keruh \\
$70 \mathrm{mg} / \mathrm{ml}$ & Keruh & Keruh & Keruh & Keruh \\
$80 \mathrm{mg} / \mathrm{ml}$ & Keruh & Keruh & Keruh & Keruh \\
$90 \mathrm{mg} / \mathrm{ml}$ & Keruh & Keruh & Keruh & Keruh \\
$100 \mathrm{mg} / \mathrm{ml}$ & Jernih & Jernih & Jernih & Jernih \\
$\mathrm{K}(+)$ & Jernih & Jernih & Jernih & Jernih \\
$\mathrm{K}(-)$ & Keruh & Keruh & Keruh & Keruh \\
Kontrol & Jernih & Jernih & Jernih & Jernih \\
madu & & & & \\
\hline
\end{tabular}


Tabel 2 Hasil Konsentrasi Bunuh Minimal (KBM)

\begin{tabular}{|c|c|c|c|c|}
\hline \multirow{3}{*}{$\begin{array}{c}\text { Konsentrasi } \\
\text { Madu }\end{array}$} & \multicolumn{3}{|c|}{ Jumlah koloni (CFU/Plate) pada } & \multirow{3}{*}{ Rata-rata } \\
\hline & & Jlanga & & \\
\hline & I & II & III & \\
\hline $60 \mathrm{mg} / \mathrm{ml}$ & 145 & 157 & 152 & 151 \\
\hline $70 \mathrm{mg} / \mathrm{ml}$ & 103 & 97 & 115 & 105 \\
\hline $80 \mathrm{mg} / \mathrm{ml}$ & 64 & 54 & 48 & 55 \\
\hline $90 \mathrm{mg} / \mathrm{ml}$ & 21 & 16 & 10 & 16 \\
\hline $100 \mathrm{mg} / \mathrm{ml}$ & 0 & 0 & 0 & 0 \\
\hline $\mathrm{K}(+)$ & 0 & 0 & 0 & 0 \\
\hline$K(-)$ & 4567 & 5213 & 4931 & 4898 \\
\hline $\begin{array}{l}\text { Kontrol } \\
\text { madu }\end{array}$ & 0 & 2 & 4 & 2 \\
\hline
\end{tabular}

Hasil rata-rata jumlah koloni tiap komsentrasi pada penentuan Konsentrasi Bunuh Minimal (KBM) disajikan dalam bentuk grafik pada gambar 1.

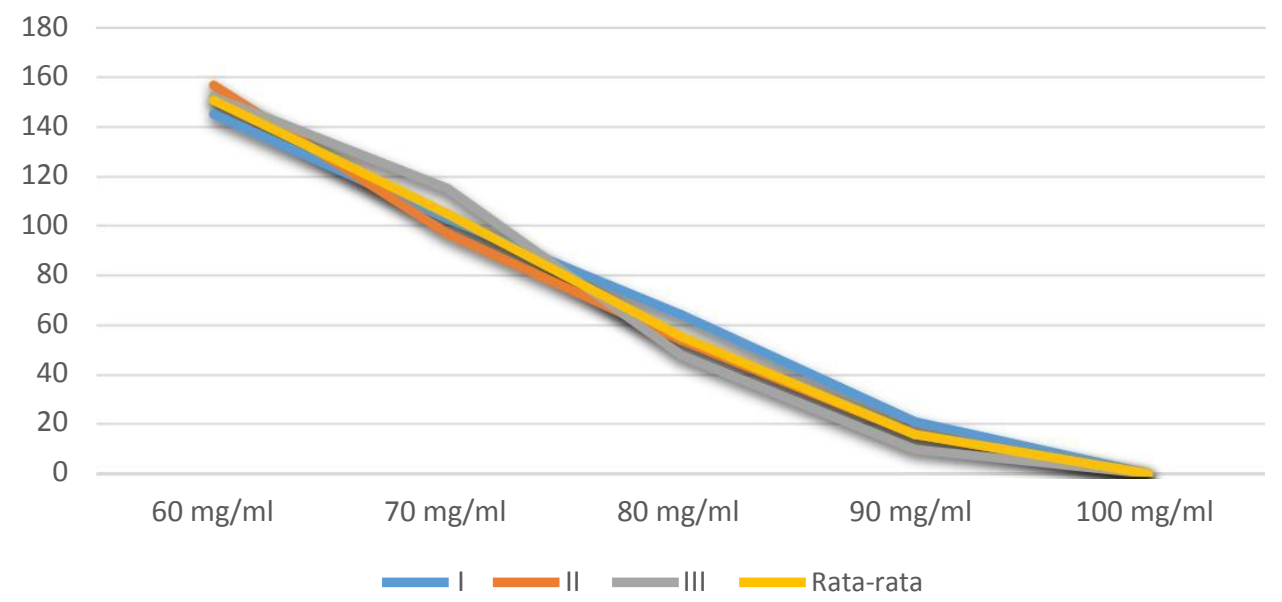

Gambar 1 Grafik Konsentrasi Bunuh Minimal (KBM)

Berdasarkan hasil konsentrasi bunuh minimal diperoleh adanya penurunan jumlah koloni pada pemberian berbagai konsentrasi madu lebah kelulut sehingga dilakukan uji normalitas data untuk mengetahui data yang digunakan berdistribusi normal atau tidak karena syarat uji one way Anova dan uji post hoc LSD yaitu data harus berdistribusi normal. Berdasarkan hasil uji normalitas data dengan menggunakan Shapiro-Wilk, diketahui nilai asymp. Sig $=0,063$. Sedangkan uji homogenitas diketahui nilai asymp. Sig $=0,182$. Apabila nila asymp. Sig >0,05 maka dapat dinyatakan bahwa data konsentrasi Bunuh Minimal (KBM) berdistribusi normal dan homogen. Pengujian dilanjutkan dengan uji one way Anova, apabila nilai signifikasi pada uji one way Anova $<0,05$. Berdasarkan hasil uji one way Anova diperoleh nilai signifikasi 0,000 sehingga persamaan yang didapat layak untuk digunakan. Pengujian dilanjutkan ke uji post hoc LSD untuk mengetahui perbedaan jumlah koloni yang tumbuh pada perlakuan konsentrasi yang berbeda dilakukan uji post hoc LSD. Apabila nilai signifikasi $<a=0,05$ maka dapat dinyatakan bahwa perlakuan konsentrasi yang berbeda dari madu lebah kelulut terhadap 
bakteri Staphylococcus aureus resisten sefalosporin secara in vitro terdapat perbedaan bermakna pada setiap konsentrasinya.

Hasil penelitian menunjukkan bahwa semakin tinggi tingkat konsentrasi madu lebah kelulut yang ditambahkan, semakin besar pula kemampuan daya hambat dan daya bunuh terhadap pertumbuhan bakteri Staphylococcus aureus resisten sefalosporin. Berdasarkan hasil uji post hoc LSD didapatkan nilai signifikasi $<a=0,05$ maka dapat dinyatakan bahwa terdapat perbedaan bermakna pada setiap konsentrasinya. Menurut Hamad (2007) Kandungan fruktosa dan glukosa pada madu melalui proses osmosis akan menyebabkan sel bakteri dehidrasi karena air banyak keluar dan menyebabkan bakteri mudah lisis. Keasaman madu yang tinggi dengan $\mathrm{pH}$ 3,2-4,5 menyebabkan terhambatnya proses metabolisme sel bakteri dimana zat-zat yang dibutuhkan bakteri untuk bertahan hidup tidak tersedia sehingga memudahkan terjadinya lisis (8).

Menurut Sulaiman (2010) Kandungan $\mathrm{H}_{2} \mathrm{O}_{2}$ yang sitotoksik menyebabkan formasi radikal bebas merusak struktur sel bakteri termasuk dinding sel dan membran sel, sehingga memudahkan sel bakteri lisis dan menghambat pertumbuhan bakteri (9).

Penelitian Boorn et.al 2009 tentang madu Trigona carbonaria yang berasal dari Brisbane, Queensland, Australia menunjukkan KHM dan KBM untuk Staphylococcus aureus $3,3 \%$ dan $4,0 \%$, Salmonella typhimurium $10,3 \%$ dan $13,2 \%$, Candida albicans $49,7 \%$ dan 53,0\% (10). Penelitian Boorn ini menjelaskan bahwa madu kelulut lebih efektif terhadap bakteri golongan Gram positif dibandingkan Gram negatif. Bakteri Gram negatif seperti Salmonella typhi menunjukkan hasil hambatan yang berbeda terhadap bahan alam lain. Penelitian dari Ratih dkk, 2015 menggunakan binahong menghasilkan daya hambat pada konsentrasi $100 \%$ sebesar $11 \mathrm{~mm}$ (11).

Dibandingkan hasil penelitian Hijriah dkk dengan Kadar Hambat Minimun (KHM) madu lebah kelulut terhadap Staphylococcus aureus pada konsentrasi $37,5 \%$ dan Kadar Bunuh Minimum (KBM) pada konsentrasi 50\%(12) maka hasil penelitian ini berada pada konsentrasi yang lebih tinggi. Daya hambat madu terhadap bakteri dapat ditentukan dari zat aktif yang dikandungnya. Zat aktif ini dimungkinkan mempunyai kadar berbeda pada lebah dengan nektar yang berbeda.

\section{KESIMPULAN}

Konsetrasi Hambat Minimal (KHM) madu lebah kelulut (Trigona spp.) terhadap bakteri Staphylococcus aureus resisten sefalosporin terjadi pada konsentrasi 100 $\mathrm{mg} / \mathrm{ml}$. Konsentrasi Bunuh Minimal (KBM) madu lebah kelulut (Trigona spp.) terhadap bakteri Staphylococcus aureus resisten sefalosporin terjadi pada konsentrasi 100 $\mathrm{mg} / \mathrm{ml}$. Madu lebah kelulut (Trigona spp.) efektif dalam menghambat dan membunuh bakteri Staphylococcus aureus resisten sefalosporin secara in vitro.

\section{DAFTAR PUSTAKA}

[1] R. D. Dwiyanti and L. Lutpiatina, "Mutu Bakteriologis Saus Tomat Pentol di Banjarbaru," Med. Lab. Technol. J., vol. 2, no. 1, pp. 1-5, 2016.

[2] R. D. Dwiyanti, A. Muhlisin, and A. Muntaha, "MRSA dan VRSA Pada Paramedis RSUD Ratu Zalecha Martapura," Med. Lab. Technol. J., vol. 1, no. 1, pp. 27-33, 2015.

[3] Amalia, R. D. Dwiyanti, and Haitami, "Daya Hambat $\mathrm{NaCl}$ Terhadap Pertumbuhan Staphylococcus aureus," Med. Lab. Technol. J., vol. 2, no. 2, pp. 42-45, 2016. 
[4] L. Lutpiatina, "Pewarnaan Gram Buffy Coat Untuk Deteksi Awal Pasien Bakteremia," Med. Lab. Technol. J., vol. 1, no. 1, pp. 38-46, 2015.

[5] Sun, T., et al. "The imoact of psychological capital on job embeddedness and job performance among nurse : A structural equation approach," J. Adv. Nurs., vol. 61, 2011.

[6] Haryanto, B., Hasan, Z., Kuswandi \& Artika, "Penggunaan Propolis untuk Meningkatkan Produktivitas Ternak Sapi Peranakan Ongole (PO)," JITV, vol. 17, no. 3, p. 202, 2012.

[7] A. Rahmi, E. Roebiakto, and L. Lutpiatina, "Potensi Ekstrak Rimpang Kencur ( Kaempferia galanga L.) Menghambat Pertumbuhan Candida albicans," Med. Lab. Technol. J., vol. 2, no. 2, pp. 70-76, 2016.

[8] S. Hamad, Terapi Madu: Panduan Praktis untuk 84 Penyakit, Plus untuk Stamina Mental. Depok: Pustaka IIman, 2007.

[9] S. Sulaiman, Terapi dengan Madu: Dar Al-Faruq Lin Nasyr wat Tauzi. Surakarta, 2010.

[10] Boorn K.L., Khor Y.Y., Sweetman E., Tan F., Heard T.A., "Antimicrobial activity of honey from the stingless bee Trigona carbonaria determined by agar diffusion, agar dilution, broth microdilution and time kill methodology," J. Appl. Microbiol., no. 108, pp. 1534-1543, 2009.

[11] R. D. Dwiyanti, Nurlailah, and I. K. Widiningsih, "Efektivitas Air Rebusan Daun Binahong (Anredera cordifolia) Terhadap Pertumbuhan Salmonella typhi," Med. Lab. Technol. J., vol. 1, no. 1, pp. 1-6, 2015.

[12] Hijriah, R., Winarsih, S., "Efek Antibakteri Madu Apel dan Madu Klanceng terhadap Staphylococcus aureus Isolat 034p secar a In Vitro," J. Penelit. Fak. Kedokt. Univ. Brawijaya Malang, 2014. 